\title{
Effect of Combustion Chamber Shapes on the Performance of Mahua and Neem Biodiesel Operated Diesel Engines
}

Banapurmath NR ${ }^{1 *}$, Chavan AS ${ }^{2}$, Bansode SB², Sankalp Patil ${ }^{1}$, Naveen G $^{1}$, Sanketh Tonannavar ${ }^{1}$, Keerthi Kumar ${ }^{3}$ andTandale MS ${ }^{2}$

${ }^{1}$ B. V.B College of Engineering and Technology, Hubli, Karnataka, India

${ }^{2}$ Dr. Babasaheb Ambedkar Technological University, Lonere, Raigad, MS, India

${ }^{3}$ B.M.S. Institute of Technology and Management, Bangalore, Karnataka, India

\begin{abstract}
Shape of combustion chamber plays a major role in controlling combustion process and emission characteristics occurring inside internal combustion engines in general and diesel engines in particular. To optimize a combustion chamber for diesel engine applications, suitable design modifications are required that meet both emission norms as well as acceptable engine performance. In this context, experimental investigations were carried out on a single cylinder four stroke direct injection diesel engine operated in single fuel mode using Mahua oil methyl ester (MhOME) and neem oil methyl ester (NOME). Different combustion chamber shapes were designed and fabricated keeping the compression ratio same for the existing diesel engine. The existing engine was provided with hemispherical combustion chamber (HCC) shape. In order to study the effect of other combustion chamber shapes on the performance of diesel engine, cylindrical (CCC), trapezoidal (TrCC), and toroidal combustion chamber (TCC) shapes were designed and developed. Various engine parameters such as power, torque, fuel consumption, and exhaust temperature, combustion parameters such as heat release rate, ignition delay, combustion duration, and exhaust emissions such as smoke opacity, hydrocarbon, $\mathrm{CO}$, and NOx, were measured. Results revealed that the TCC shape resulted in overall improved performance with reduced emission levels compared to other shapes tested. Total hydrocarbon emission (THC) and carbon monoxide (CO) were also decreased significantly compared to other combustion chambers.
\end{abstract}

Keywords: Biodiesel; Mahua oil; Neem oil; Emissions; Combustion chamber shapes

\section{Introduction}

Diesel engines are widely used for transport and power generation applications because of their high thermal efficiency, and their easy adoption for power generation applications as well. However, there is an increased impetus on improved engine performance, lower noise and vibration levels and lower emissions. Increasing energy demand, decrease in fossil fuel reserve in the earth crust and harmful exhaust gases have focused major attention on the use of renewable and alternative fuels. To overcome and meet these demands, use of renewable fuels such as biodiesels for diesel engines has gained greater momentum. To meet the challenge, it is essential in implementing new technologies and methods that improve the efficiency of diesel engine used for both transport and power generation applications. Renewable energy sources can supply the energy for longer periods of time than those of fossil fuels and have many advantages [1]. Liquid biodiesels are more suitable for diesel engine applications as their properties are closer to diesel.

A number of vegetable oils have been used for biodiesel production and their respective biodiesels are used as alternative fuels in diesel engines. Biodiesels derived from jatropha, honge (karanja), honne, palm, rubber seed, rape seed, mahua, and neem seed oils were used in diesel engine applications [2-14]. Slightly lowered performance with increased emissions and combustion studies was reported for Biodiesels engine operation by several researchers [2,3,8,9,15-17]. Effect of various engine parameters such as compression ratio (CR), injection timing (IT), injection pressure and engine loading on the performance and exhaust emissions of a single cylinder diesel engine operated on biodiesel and their blends with diesel were reported in the literature [18]. Changes in injection timings change the position of the piston and cylinder pressure and temperature at the injection. Retarded injection timings showed significant reduction in diesel NOx and biodiesel NOx [19]. Cylinder pressures and temperatures gradually decreased when injection timings were retarded [20]. Other investigators also have performed experiments on CI engine with different vegetable oils and their esters at different injection pressures. Better performance, higher peak cylinder pressure and temperature were reported at increased injection pressures [20-23].

\section{Mahua and Neem Biodiesel Operation}

Biodiesels derived from Mahua and Neem oils have been used as potential alternative fuels to diesel by several investigator. Mahua biodiesel has been used as an alternative fuel for diesel engine application by several investigators [22,24,25]. Effect of injection timing, compression ratio on the performance of Mahua biodiesel has been reported [26]. They reported biodiesel could be blended with diesel fuel up to $20 \%$ at any compression ratio and injection timing for getting nearly same performance as compared with diesel. For neem biodiesel a slight drop in efficiency compared to diesel has been reported, while their blends B10, B20 showed performance closer to diesel operation $[27,28]$. CO emission increased with B100 and increased blends of B60, B80 due to the incomplete combustion. They suggested a change in

*Corresponding author: Dr. N.R. Banapurmath, B.V.B. College of Engineering and Technology, Hubli, Karnataka, India, Tel: +919880726748; Fax: +918362374985; E-mail: nr_banapurmath@rediffmail.com

Received May 05, 2015; Accepted June 08, 2015; Published June 15, 2015

Citation: Banapurmath NR, Chavan AS, Bansode SB, Sankalp Patil, Naveen G, et al. (2015) Effect of Combustion Chamber Shapes on the Performance of Mahua and Neem Biodiesel Operated Diesel Engines. J Pet Environ Biotechnol 6: 230. doi:10.4172/2157-7463.1000230

Copyright: (c) 2015 Banapurmath NR, et al. This is an open-access article distributed under the terms of the Creative Commons Attribution License, which permits unrestricted use, distribution, and reproduction in any medium, provided the original author and source are credited. 
Citation: Banapurmath NR, Chavan AS, Bansode SB, Sankalp Patil, Naveen G, et al. (2015) Effect of Combustion Chamber Shapes on the Performance of Mahua and Neem Biodiesel Operated Diesel Engines. J Pet Environ Biotechnol 6: 230. doi:10.4172/2157-7463.1000230

Page 2 of 7

injection pressure and combustion chamber design for better engine performance. Neem oil methyl ester resulted in lower emissions compared to diesel whereas neem oil gives lower $\mathrm{CO}_{2}$ emission due to incomplete combustion while smoke opacity increased at part load and decreased at full load [28].

The combustion chamber of an engine plays a major role during the combustion of wide variety of fuels. In this context, many researchers performed both experimental and simulation studies on the use of various combustion chambers [29-31]. Improvement in air entrainment with increased swirl and injection pressure were reported $[32,33]$. Optimum combustion chamber geometry of the engine showed better performance and emission levels. Suitable combustion geometry of bowl shape helps to increase squish area and proper mixing of gaseous fuel with air [29,34]. Designing the combustion chamber with narrow and deep and with a shallow reentrance had a low protuberance on the cylinder axis and the spray oriented towards the bowl entrance reduced the NOx emission levels to the maximum extent $[30,31,35]$. The behavior of fuel once it is injected in the combustion chamber and its interaction with air is important. It is well known that nozzle geometry and cavitations strongly affect evaporation and atomization processes of fuel. Suitable changes in the in-cylinder flow field resulted in differing combustion.

From the literature survey it follows that very limited work has been done to investigate the effect of combustion chamber shapes on the performance, combustion and emission characteristics of diesel engine fuelled with Mahua and Neem oil methyl esters. In this context, experimental investigations were carried out on a single cylinder four stroke direct injection diesel engine operated on MhOME and NOME with different combustion chamber shapes adopted for this work.

\section{Characterization of Mahua and Neem Oils}

In the present study, Diesel, MhOME and NOME were used as injected fuels. Tables 1 and 2 shows the composition of MhOME and NOME, fatty acids contribution, chemical formula, structure and their molecular weight with their chemical structure. The properties of MhOME and NOME were determined experimentally and are summarized in Table 3.

\section{Experimental Setup}

Experiments were conducted on a Kirloskar TV1 type, four stroke, single cylinder, water-cooled diesel engine test rig. Figure 1 shows the line diagram of the test rig used. Eddy current dynamometer was used for loading the engine. The fuel flow rate was measured on the volumetric basis using a burette and stopwatch. The engine was operated at a rated constant speed of $1500 \mathrm{rev} / \mathrm{min}$. The emission characteristics were measured by using HARTRIDGE smoke meter and five gas analyzer during the steady state operation. Experiments were conducted by using biodiesels selected for the study with four different combustion chamber shapes (cylindrical (CCC), trapezoidal (TrCC), and toroidal Combustion chamber (TCC) shapes). Figures 2 shows the different combustion chamber shapes. Finally the results obtained with biodiesel operation were compared with Diesel. The specification of the compression ignition (CI) engine is given in Table 4.

\section{Results and Discussions}

In the present work, diesel engine was operated on diesel, MhOME and NOME with different configurations of combustion chambers namely cylindrical (CCC), trapezoidal (TrCC), and toroidal combustion chamber (TCC) shapes. The results and discussions on the performance combustion and emission characteristics of diesel engine

\begin{tabular}{|c|c|c|c|c|c|c|c|}
\hline SI No & Composition & Chemical name & $\begin{array}{l}\text { Single/Double/ } \\
\text { Triple bond }\end{array}$ & Structure & $\begin{array}{l}\text { Saturated/ } \\
\text { Unsaturated }\end{array}$ & Chemical formula & Weight (\%) \\
\hline 1 & Palmitic & Hexadecanoic & --- & $16: 0$ & Saturated & $\mathrm{C}_{16} \mathrm{H}_{32} \mathrm{O}_{2}$ & $16.0-28.2$ \\
\hline 2 & Stearic & Octadecanoic & ---- & $18: 0$ & Saturated & $\mathrm{C}_{18} \mathrm{H}_{36} \mathrm{O}_{2}$ & $20.0-25.1$ \\
\hline 3 & Oleic & Cis-9 Octadecanoic & Single & $18: 1$ & Unsaturated & $\mathrm{C}_{18} \mathrm{H}_{34} \mathrm{O}_{2}$ & $41.0-51.0$ \\
\hline 4 & Linoleic & $\begin{array}{c}\text { Cis-9,cis-12 } \\
\text { Octadecanoic }\end{array}$ & Double & $18: 2$ & Unsaturated & $\mathrm{C}_{18} \mathrm{H}_{32} \mathrm{O}_{2}$ & $8.9-13.7$ \\
\hline 5 & Arachidic & Etcosanoic & ---- & $20: 0$ & Saturated & $\mathrm{C}_{20} \mathrm{H}_{40} \mathrm{O}_{2}$ & $0.0-3.3$ \\
\hline
\end{tabular}

Table 1: Fatty acid contribution of Mahua oils sample and its chemical structure.

\begin{tabular}{|c|c|c|c|c|c|c|c|}
\hline SI No & Composition & Chemical name & $\begin{array}{l}\text { Single/Double/ } \\
\text { Triple bond }\end{array}$ & Structure & $\begin{array}{l}\text { Saturated/ } \\
\text { Unsaturated }\end{array}$ & Chemical formula & $\begin{array}{c}\text { Weight(\%) } \\
\text { Or Molecular wt }\end{array}$ \\
\hline 1 & Palmitic & Hexadecanoic & ---- & 16:0 & Saturated & $\mathrm{C}_{16} \mathrm{H}_{32} \mathrm{O}_{2}$ & $16.0-28.2$ \\
\hline 2 & Stearic & Octadecanoic & --- & $18: 0$ & Saturated & $\mathrm{C}_{18} \mathrm{H}_{36} \mathrm{O}_{2}$ & $20.0-25.1$ \\
\hline 3 & Oleic & Cis-9 Octadecanoic & Single & $18: 1$ & Unsaturated & $\mathrm{C}_{18} \mathrm{H}_{34} \mathrm{O}_{2}$ & $41.0-51.0$ \\
\hline 4 & Linoleic & $\begin{array}{l}\text { Cis-9,cis-12 } \\
\text { Octadecanoic }\end{array}$ & Double & $18: 2$ & Unsaturated & $\mathrm{C}_{18} \mathrm{H}_{32} \mathrm{O}_{2}$ & $8.9-13.7$ \\
\hline 5 & Arachidic & Etcosanoic & ---- & $20: 0$ & Saturated & $\mathrm{C}_{20} \mathrm{H}_{40} \mathrm{O}_{2}$ & $0.0-3.3$ \\
\hline
\end{tabular}

Table 2: Fatty acid contribution of Neem oils sample and its chemical structure.

\begin{tabular}{|c|c|c|c|c|c|c|}
\hline SI No & Properties & Diesel & Mahua oil & Neem oil & MhOME & NOME \\
\hline 1 & Viscosity@40C (cst) & 4.59 (Low) & 24.21 & 23.45 & 5.6 & 4.7 \\
\hline 2 & Flash point ${ }^{\circ} \mathrm{C}$ & 56 & 212 & 210 & 129 & 118 \\
\hline 3 & Calorific value in $\mathrm{kJ} / \mathrm{kg}$ & 45000 & 36,100 & 38,100 & 36,900 & 40,000 \\
\hline 4 & Specific gravity & 0.830 & 0.960 & 0.940 & 0.882 & 0.878 \\
\hline 5 & Density $\mathrm{Kg} / \mathrm{m}^{3}$ & 830 & 960 & 940 & 882 & 878 \\
\hline 8 & Type of oil & ---- & Non edible & Non edible & Non edible & Non edible \\
\hline 9 & Cetane number & 42 & --- & ---- & 52 & 52 \\
\hline
\end{tabular}

Table 3: Properties of fuels tested. 
Citation: Banapurmath NR, Chavan AS, Bansode SB, Sankalp Patil, Naveen G, et al. (2015) Effect of Combustion Chamber Shapes on the Performance of Mahua and Neem Biodiesel Operated Diesel Engines. J Pet Environ Biotechnol 6: 230. doi:10.4172/2157-7463.1000230

Page 3 of 7

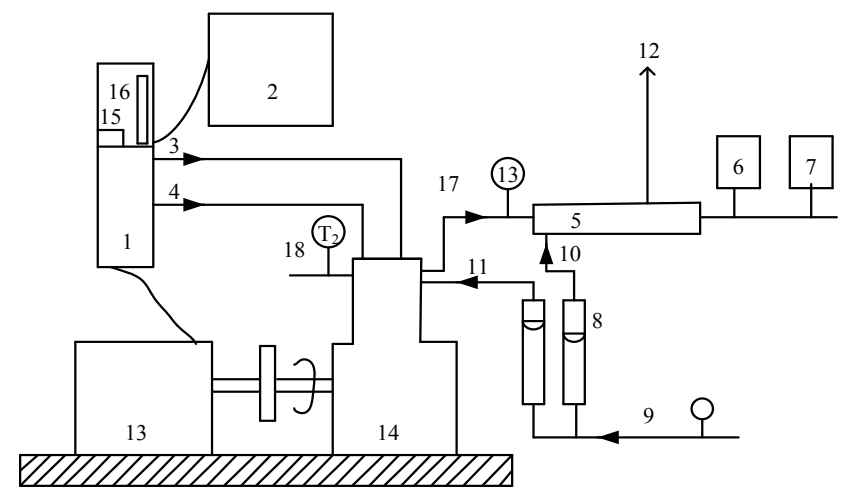

1-Control Panel, 2-Computer system, 3-Diesel flow line, 4-Air flow line, 5-Calorimeter, 6-Exhaust gas analyzer, 7-Smoke meter, 8-Rota meter, 9 , 11-Inlet water temperature, 10-Calorimeter inlet water temperature,12Calorimeter outlet water temperature, 13-Dynamometer, 14-Cl Engine, 15-Speed measurement,16-Burette for fuel measurement, 17-Exhaust gas outlet, 18-Outlet water temperature, T1- Inlet water temperature, T2-Outlet water temperature, T3-Exhaust gas temperature.

Figure 1: Experimental set up.

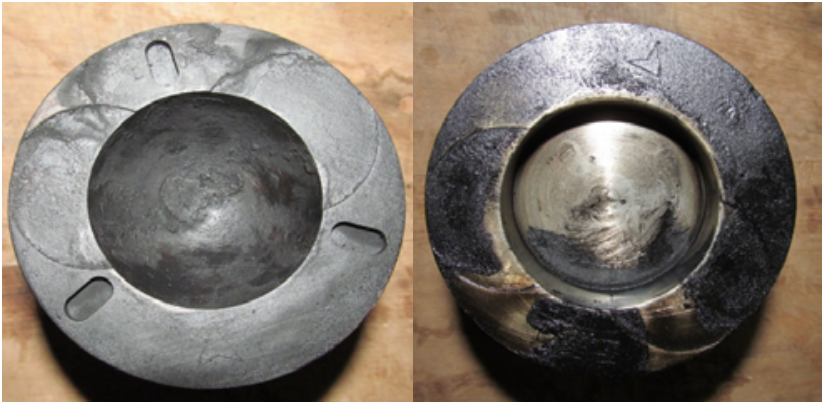

(a) Hemispherical

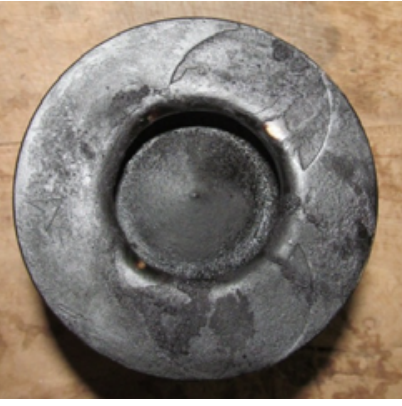

(c) Toroidal (b) Cylindrical

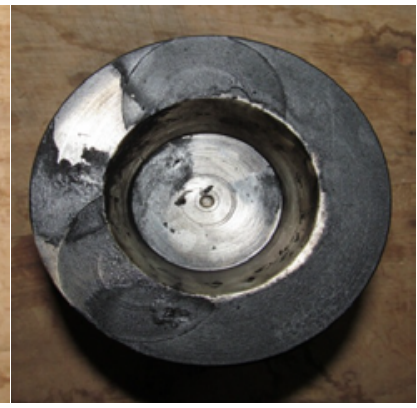

(d) Trapezoidal
Figure 2: Combustion chamber shapes.

\begin{tabular}{|l|l|l|}
\hline SI No & Parameters & Specification \\
\hline 1 & Type of engine & $\begin{array}{l}\text { Kirloskar make Single cylinder four stroke } \\
\text { direct injection diesel engine }\end{array}$ \\
\hline 2 & Nozzle opening pressure & 200 to 205 bar \\
\hline 3 & Rated power & $5.2 \mathrm{KW}$ (7 HP)@1500 RPM \\
\hline 4 & Cylinder diameter (Bore) & $87.5 \mathrm{~mm}$ \\
\hline 5 & Stroke length & $110 \mathrm{~mm}$ \\
\hline 6 & Compression ratio & $17.5: 1$ \\
\hline
\end{tabular}

Table 4: Specifications of the engine. operating on two biodiesels is presented in the subsequent paragraphs.

\section{Performance and emission characteristics}

Figure 3 shows the variation of brake thermal efficiency (BTE) with brake power. It is observed that BTE for diesel fuel mode of operation was higher than both biodiesels of MhOME and NOME operation over the entire load range. This is mainly due to lower calorific value of the biodiesels and lower volatility as well. The study with different combustion chamber shapes showed that for biodiesel operation with TCC resulted in better performance compared to other combustion chambers. It may be due to the fact that, the TCC prevents the flame from spreading over to the squish region resulting in better mixture formation of biodiesel-air combinations, as a result of better air motion and lowers exhaust soot by increasing swirl and tumble. Based on the results, it is observed that the TCC has an ability to direct the flow field inside the sub volume at all engine loads and therefore substantial differences in the mixing process may not be present.

Figure 4 shows variation of smoke opacity with brake power. It is observed that the smoke opacity for diesel fuel operation was lower than MhOME and NOME biodiesels over the entire load range. This may be attributed to improper fuel-air mixing due to higher viscosity and higher free fatty acid content of biodiesels considered. However, TCC gives lower smoke emission levels compared to other combustion chambers. It may be due to the fact that, the air-fuel mixing prevailing inside combustion chamber and higher turbulence resulted in better combustion and oxidation of the soot particles which further reduction the smoke emission levels.
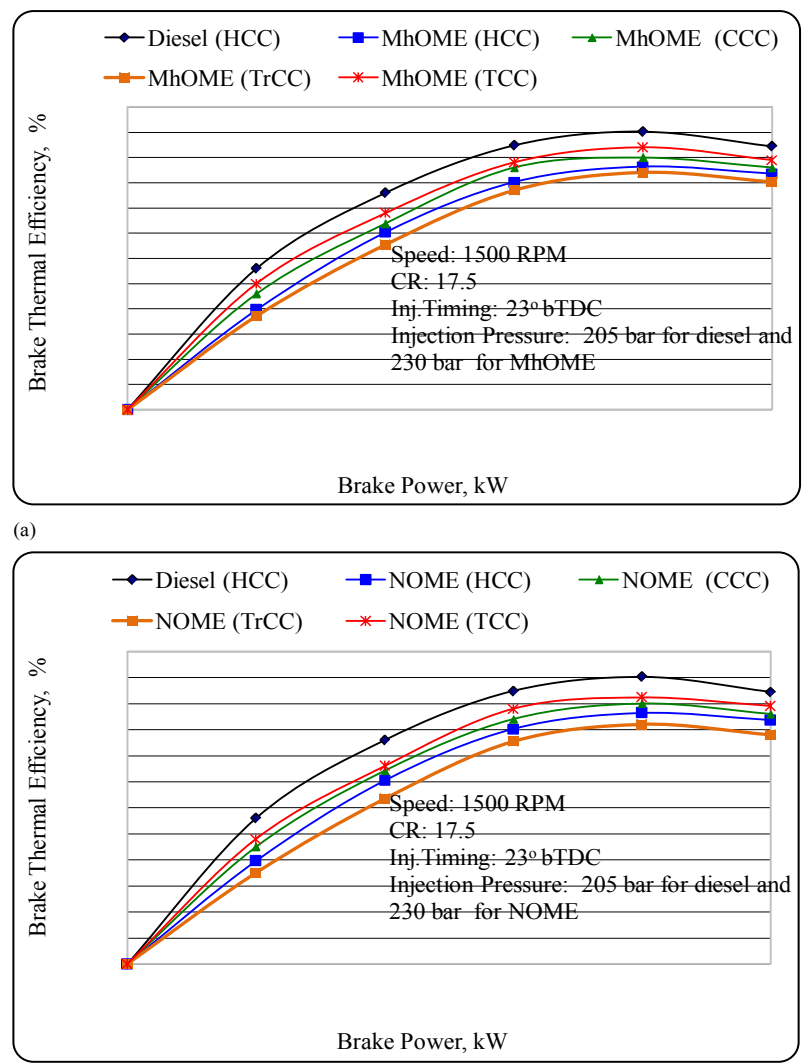

(b) 
Citation: Banapurmath NR, Chavan AS, Bansode SB, Sankalp Patil, Naveen G, et al. (2015) Effect of Combustion Chamber Shapes on the Performance of Mahua and Neem Biodiesel Operated Diesel Engines. J Pet Environ Biotechnol 6: 230. doi:10.4172/2157-7463.1000230

Page 4 of 7

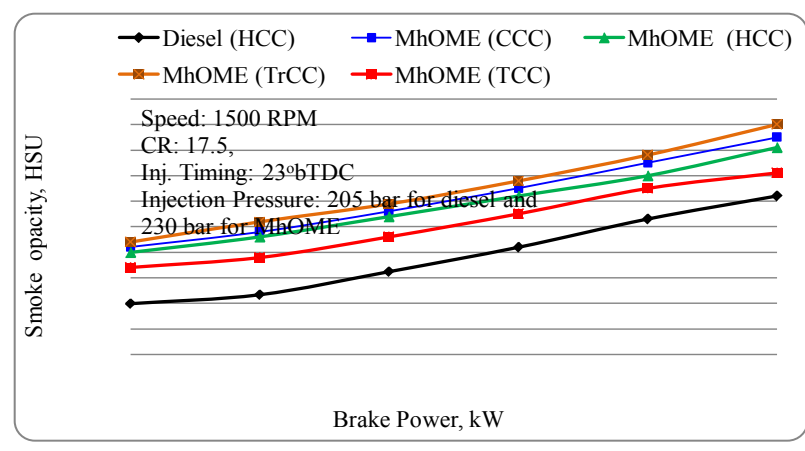

(a)

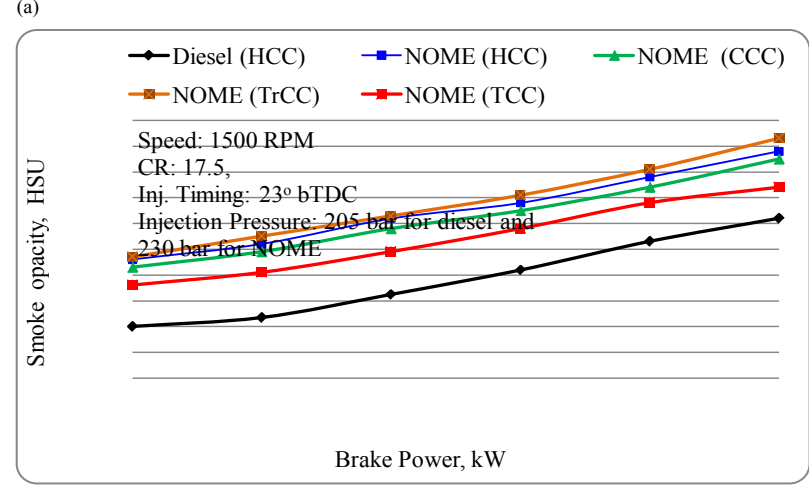

(b)

Figure 4: Variation of Smoke opacity with BP.

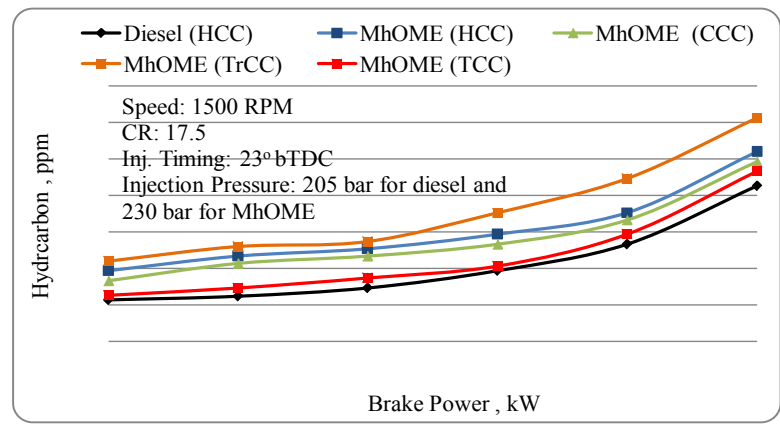

(a)

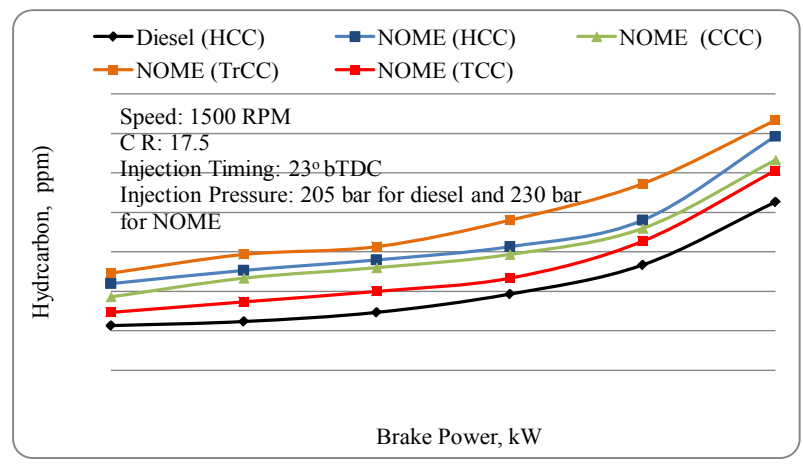

(b)

Figure 5: Variation of $\mathrm{HC}$ with $\mathrm{BP}$
Figures 5 and 6 shows the variation of hydrocarbon (HC) and carbon monoxide (CO) emission levels for diesel, MhOME, and NOME at all loads. Both $\mathrm{HC}$ and $\mathrm{CO}$ emission levels were higher for MhOME, and NOME compared to diesel operation. Incomplete combustion of the MhOME, and NOME biodiesels is responsible for this observed trend. It could be due to their lower calorific value, lower adiabatic flame temperature and higher viscosity and lower mean effective pressures. However, TCC resulted in lower HC and CO emission levels compared to other combustion chamber shapes. It could be due to higher turbulence and comparatively higher temperature prevailing in the combustion chamber that resulted into minimum heat losses and better oxidation of $\mathrm{HC}$ and $\mathrm{CO}$ and hence reduced both emission levels. However, other combustion chambers may not contribute to the proper mixing fuel combinations.

The NOx emission levels were found to be higher for diesel fuel operation compared to biodiesel over the entire load range (Figure 7). This is because of higher heat release rate during premixed combustion phase observed with diesel compared to biodiesel operation. Slightly higher NOx resulted with TCC compared to other combustion chambers tested. This could be due to slightly better combustion occurring due to more homogeneous mixing and larger part of combustion occurs just before top dead center. Presence of oxygen in the biodiesels is also responsible for this trend. Therefore it is resulted in higher peak cycle temperature.

\section{Combustion characteristics}

In this section combustion characteristics of diesel engine fuelled with MhOME, NOME biodiesel has been presented

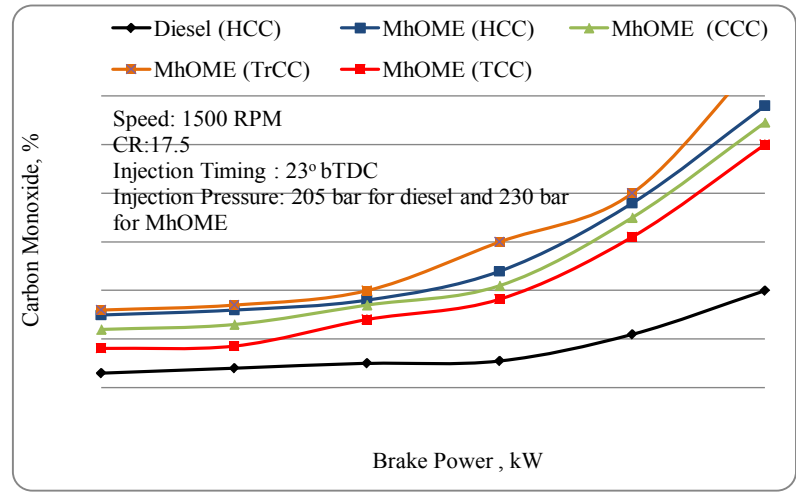

(a)

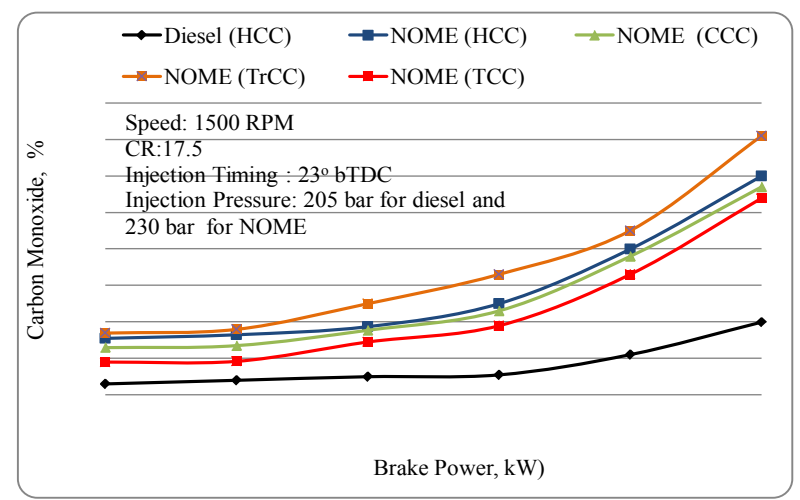

(b)

Figure 6: Variation of $\mathrm{CO}$ with $\mathrm{BP}$. 


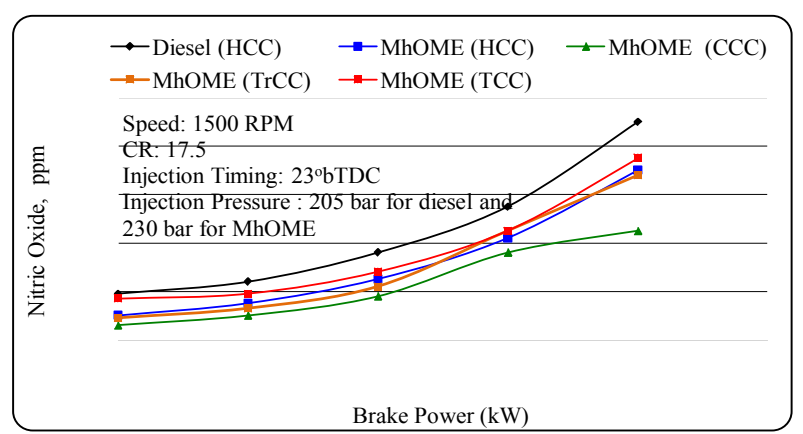

(a)

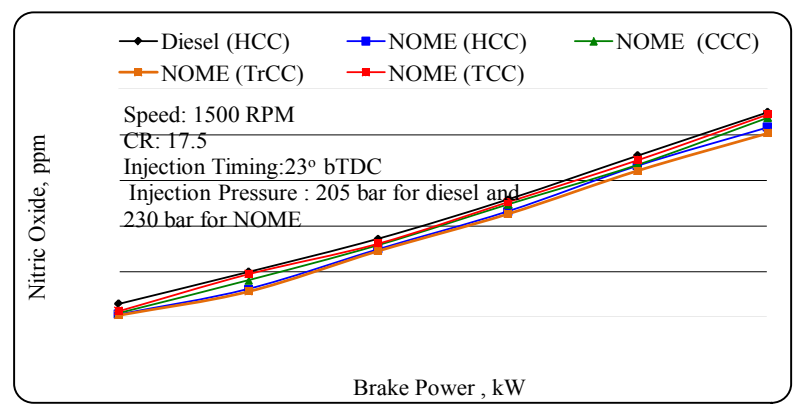

(b)

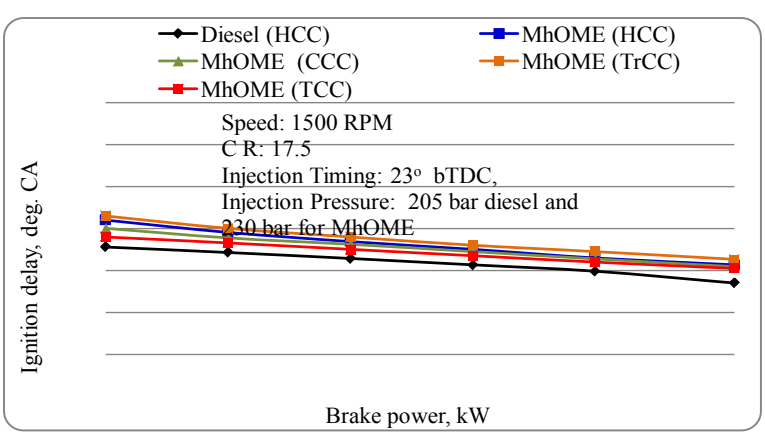

(c)

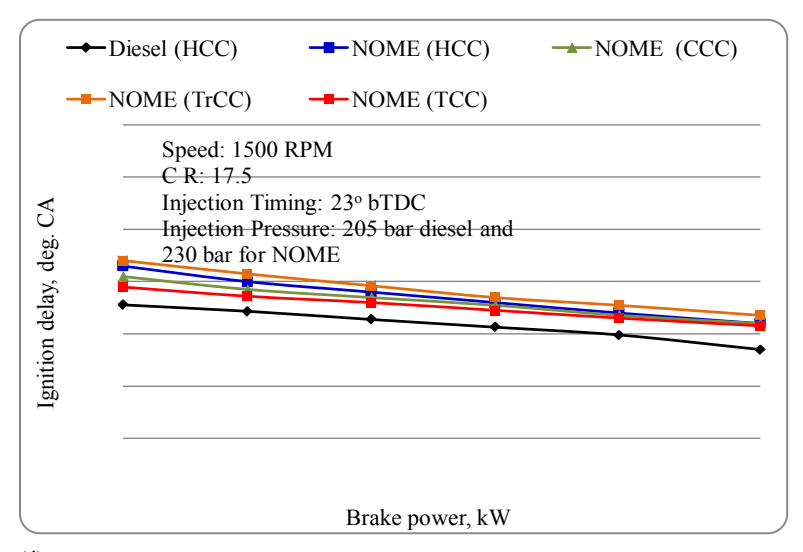

(d)

Figure 7: Variation of ignition delay with BPandVariation of $\mathrm{NO}_{x}$ with $\mathrm{BP}$.

Ignition delay: The variation of ignition delay with brake power for different combustion chamber shapes were shown in Figure 8. The ignition delay is calculated based on the static injection timing.
It is observed that ignition delay decreased with an increase in brake power for almost all combustion chamber shapes. With an increase in brake power, the amount of fuel being burnt inside the cylinder gets increased and subsequently the temperature of in-cylinder gases gets increased. This leads to reduced ignition delay with all combustion chamber shapes. However, the ignition delay for diesel was lower compared to biodiesel operation with all combustion chamber shapes. However, lower ignition delays were observed for biodiesel operation with TCC compared to the operation with HCC, CCC and TrCC. It could be attributed to better air-fuel mixing and increased combustion temperature.

Combustion duration: The combustion duration shown in Figure 8 was calculated based on the duration between the start of combustion and $90 \%$ cumulative heat release. The combustion duration increases with increase in the power output with all combustion chamber shapes. This is due to the amount of fuel being burnt inside the cylinder gets increased. Combustion chamber being same, higher combustion duration was observed with biodiesel compared to diesel operation. It could be due to higher viscosity of biodiesels leading to improper air-fuel mixing, and needs longer time for mixing and hence resulting in incomplete combustion with longer diffusion combustion phase. However with combustion duration was reduced with TCC compared to other combustion chambers tested. This could be attributed to improvement in mixing of fuel combination due to better squish. Significantly higher combustion rates with biodiesel operation leads to higher exhaust temperatures and lower thermal efficiency. However, biodiesel operation with TCC showed improvement in heat release rate compared to other combustion chamber shapes.

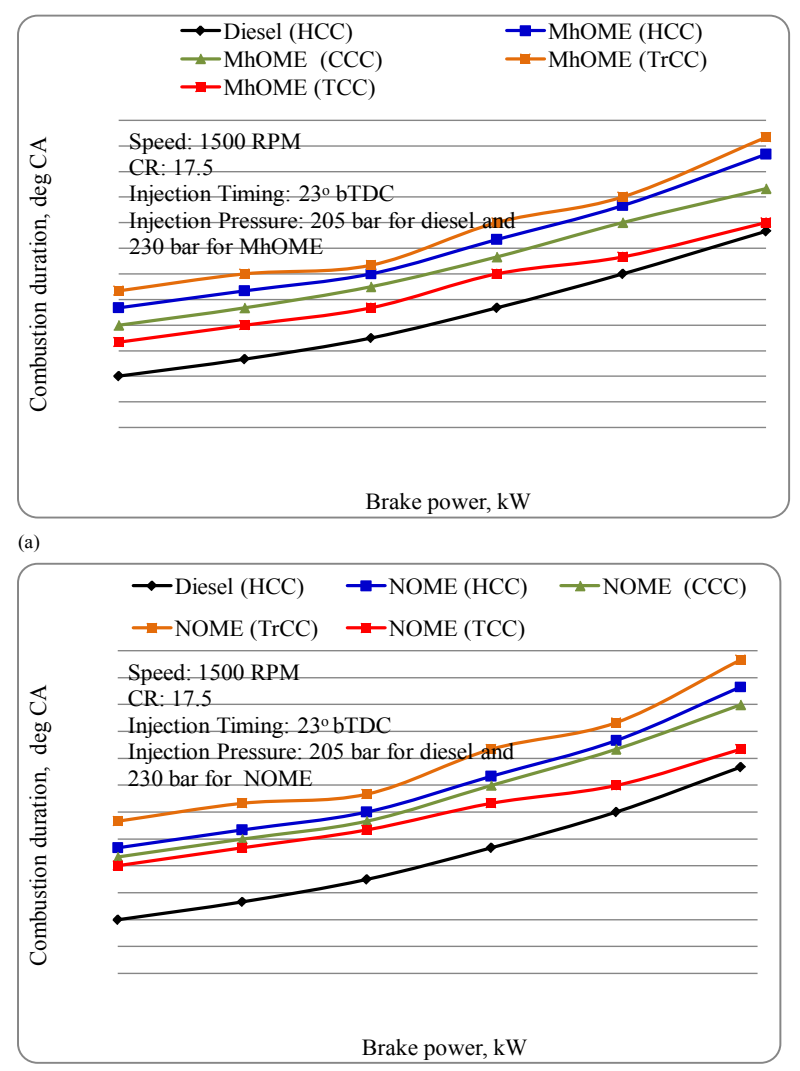

(b)

Figure 8: Variation of combustion duration with BP. 


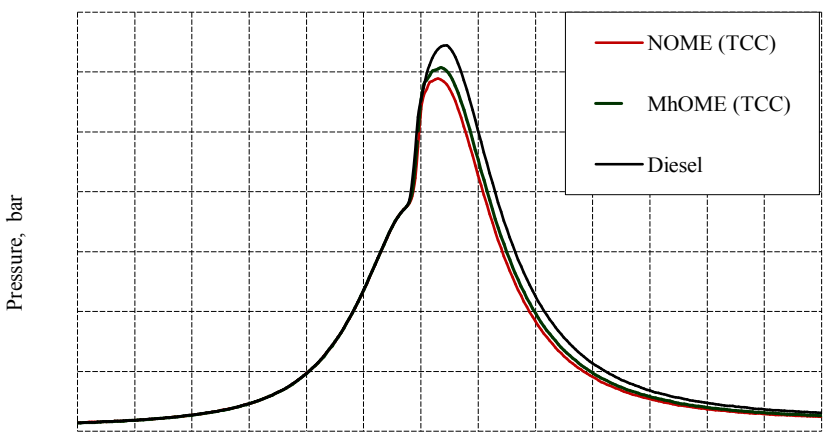

Crank angle, degree $\mathrm{CA}$

Figure 9: In-cylinder pressure versus crank angle at varying compression ratio for NOME and MhOME biodiesels at $80 \%$ load.

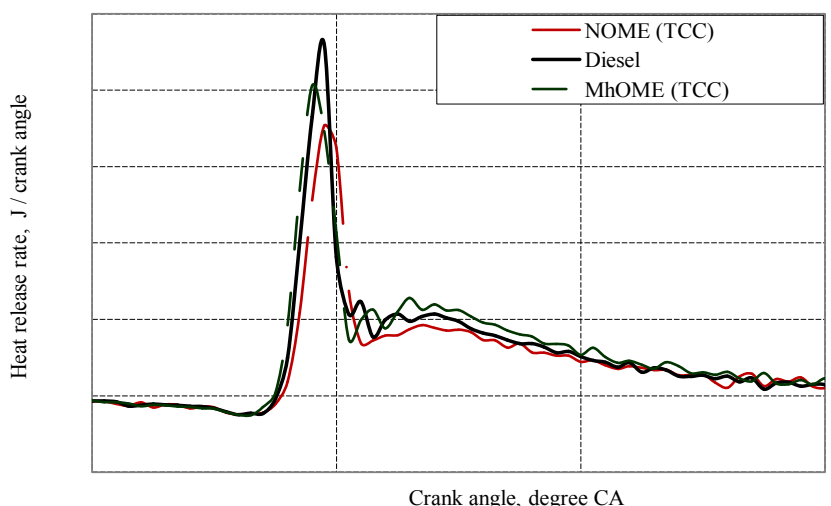

Figure 10: Rate of heat release versus crank angle at varying compression ratio for NOME and MhOME biodiesels at $80 \%$ load.

\section{Cylinder pressure}

Figure 9 shows the effect of combustion chamber shapes on the in-cylinder pressure operated on different fuel combinations. The peak pressure depends on the combustion rate and amount of fuel consumed during rapid combustion period. Mixture preparation and slow burning nature of biodiesel during the ignition delay period were responsible for peak pressure and maximum rate of pressure rise.

Results showed that biodiesel with TCC resulted in higher peak pressure as shown in Figure 9. The pressure for MhOME biodiesel operation with TCC was higher compared to NOME biodiesel tested. It could be due to the combined effect of longer ignition delay, lower adiabatic flame temperature and slow burning nature of the biodiesel operation. This could be attributed to incomplete combustion due to improper mixing of fuel combinations, reduction of air entrainment, and higher viscosity of biodiesel. The sharp increase in combustion acceleration showed increased cylinder pressure during the piston's descent and that the combustion energy as efficiently converted into work.

\section{Heat release rate}

Figure 10 shows rate of heat release versus crank angle for different two biodiesels with TCC combustion chamber shapes. Biodiesel operation for TCC resulted into higher heat release rate compared to the operation with other combustion chambers. Combustion chamber being common NOME has higher second peak in the diffusion combustion phase compared to the MhOME operation with TCC operation.

\section{Conclusions}

From the exhaustive experimentation on the use of biodiesel in diesel engines with different combustion chamber shapes the following conclusions were made for the present study.

- Both biodiesels of Mahua and Neem resulted into inferior engine performance with increased emissions compared to diesel operation. The performance was improved with TCC combustion chamber provision.

- Improved air motion, better mixture formation with TCC compared to other combustion chambers was observed.

- Higher brake thermal efficiency with lower emission levels obtained with TCC.

- Combustion chamber optimization coupled with optimized injector position further improves the diesel engine performance.

\section{References}

1. Goldemberg J, Coelhobn ST (2004) Renewable energy- traditional biomass vs. modern biomass. Energy Policy 32: 711-714.

2. Banapurmath NR, Tewari PG (2008) Combustion and emission characteristics of a Direct Injection $\mathrm{Cl}$ engine when operated on Honge oil, Honge oil methy ester (HOME) and blends of Honge oil methyl ester (HOME) and diesel. International Journal of Sustainable Engineering 1: 80-93.

3. Banapurmath NR, Tewari PG (2009) Effect of biodiesel derived from Honge oil and its blends with diesel when directly injected at different injection pressures and injection timings in single cylinder water cooled compression ignition engine. Proceedings of Institute of Mechanical Engineers, Part A: Journal of Power and Energy. Professional Engineering Publications 223: 31-40.

4. Bari S, Lim TH, Yu CW (2002) Effect of Preheating of Crude Palm Oil (CPO) on Injection System, Performance and Emission of a Diesel Engine. Renewable Energy 27: 339-351.

5. Gajendra Babu MK, Chandan Kumar, Das LM (2006) Experimental Investigations on a Karanja Oil Methyl Ester Fuelled DI Diesel Engine. Society of Automotive Engineers, Paper No.: 2006-01-0238, USA.

6. Karnwal A, Naveen Kumar MM, Chaudhary HR, Siddiquee AN, Khan ZA (2010) Production of Biodiesel from Thumba Oil: Optimization of Process Parameters Iranica. Journal of Energy \& Environment 1: 352-358.

7. Onga HC, Mahlia TMI, Masjukia HH, Norhasyimab RS (2011) Comparison of palm oil, Jatropha curcas and Calophyllum inophyllum for Biodiesel. Renewable and Sustainable Energy Reviews 15: 3501-3515.

8. Ramadhas AS, Muraleedharan C, Jayaraj S (2005) Performance and emission evaluation of a diesel engine fueled with methyl esters of rubber seed oil. Renewable Energy 30: 1789-1800.

9. Ramadhas AS, Jayaraj S, Muraleedharan C (2005) Characterization and effect of using rubber seed oil as fuel in the compression ignition engines. Renewable Energy 30: 795-803.

10. Raheman H, Phadatare AG (2004) Diesel engine emissions and performance from blends of karanja methyl ester and diesel. Biomass and Bioenergy 27 : 393-397.

11. Sahoo PK, Das LM, Babu MKJ, Naik SN (2007) Biodiesel development from high acid value polanga seed oil and performance evaluation in a $\mathrm{Cl}$ engine. Fuel 86: 448-454.

12. Sahoo PK, Das LM, Babu MKJ, Arora P, Singh VP, et al. (2009) Comparative evaluation of performance and emission characteristics of Jatropha, karanja and polanga based biodiesel as fuel in a tractor engine. Fuel 88: 1698-1707.

13. Venkanna BK, Reddy CV (2011) Performance, emission and combustion characteristics of direct injection diesel engine running on calophyllum 
Citation: Banapurmath NR, Chavan AS, Bansode SB, Sankalp Patil, Naveen G, et al. (2015) Effect of Combustion Chamber Shapes on the Performance of Mahua and Neem Biodiesel Operated Diesel Engines. J Pet Environ Biotechnol 6: 230. doi:10.4172/2157-7463.1000230

inophyllum linn oil (honne oil). International Journal of Agricultural \& Biological Engineering 4.

14. Sundraapandian S, Devaradjane G (2007) Experimental and Theoretical investigation of the performance of vegetable-oil-operated $\mathrm{Cl}$ engine. Society of Automotive Engineers, Paper No: 2007-32-0067.

15. Nwafor OMI (2000) Effect of advanced injection timing on the performance of rapeseed oil in diesel engines. Renewable Energy 21: 433-44.

16. Nwafor OMI (2003) The effect of elevated fuel inlet temperature on performance of diesel engine running on neat vegetable oil at constant speed conditions. Renewable Energy 28: 171-81.

17. Scholl KW, Sorenson SC (1993) Combustion of soyabean oil methyl ester in a direct injection diesel engine. Society of Automotive Engineers, Paper No.: 930-934.

18. Gajendra Babu MK (2007) Studies on performance and exhaust emissions of a $\mathrm{Cl}$ engine operating on diesel and diesel biodiesel blends at different injection pressures and injection timings. Society of Automotive Engineers, Paper No.: 2007-01-0613, USA.

19. Hountalas DT, Kouremenos DA, Binder KB, Raab A, Schnabel MH (2001) Using advanced Injection timing and EGR to Improve DI engine efficiency at Acceptable NO and Soot levels. Society of Automotive Engineers, Paper No.: 2001-01-0199.

20. Roy MM (2009) Effect of fuel injection timing and injection pressure on combustion and odorous emissions in DI diesel engine. Journal of Energy Resources Technology, ASME Transactions 131: 1-8.

21. Bari S, Yu CW, Lim TH (2004) Effect of fuel injection timing with waste cooking oil as a fuel in direct injection diesel engine. Proceedings of the Institution of Mechanical Engineers, Part D: Journal of Automobile Engineering 218: 93-104.

22. Puhan S, Vedaraman N, Ram BVB, Sankaranarayanan G, Jeychandran K (2005) Mahua oil (Madhuca Indica seed oil) methyl ester as biodieselpreparation and emission characteristics. Biomass Bioenergy 87-93.

23. Rosli, Abu Bakar, Abdul Rahim Ismail Semin (2008) Fuel injection pressure effect on performance of direct injection diesel engines based on experiment. American Journal of Applied Sciences 5: 197-202.
24. Godiganur S, Murthy C (2009) 6BTA 5.9 G2-1 Cummins engine performance and emission tests using methyl ester mahua (Madhuca indica) oil/diesel blends. Renewable Energy 34: 2172-2177.

25. Raheman H, Ghadge SV (2007) Performance of compression ignition engine with mahua (Madhuca indica) biodiesel. Fuel 2568-2573.

26. Raheman H, Ghadge SV (2008) Performance of diesel engine with biodiesel at varying compression ratio and ignition timing. Fuel 87: 2659-2666.

27. Rao TV, Rao GP, Reddy KHC (2008) Experimental investigation of Pongamia jatropha and neem methyl esters as biodiesel on C.I. engine. Jordan Journal of Mechanical Industrial Engineering 2: 117-122.

28. Ragit SS, Mohapatra SK, Kundu K (2010) Performance and emission evaluation of a diesel engine fuelled with methyl ester of neem oil and filtered neem oil. Journal of Scientific and Industrial Research 69: 62-66.

29. Risi AD, Donateo T, Laforga D (2003) Optimisation of combustion chambe of direct injection diesel engines. SAE International Paper No. 2003-01-1064.

30. Jaichander S, Annamalai K (2012) Performance and exhaust emission analysis on pongamia biodiesel with different open combustion chambers in a DI diese engine. Journal of scientific and industrial research 71: 487-491.

31. Matsumoto K, Inoue T, Nakanishi K, Okumura T (1977) The effects of combustion chamber design and compression ratio on emissions, fuel economy and octain number requirement. Society of Automotive Engineers.

32. Pratiba BVV, Prasanthi G (2011) Influence of in cylinder air swirl on diese engine performance and emission. International Journal of Applied Engineering and Technology 1: 113-118.

33. McCracken ME, Abraham J (2001) Swirl-Spray Interactions in a Diesel Engine. Society of Automotive Engineers 2001-01-0996.

34. Balawant ST (2012) Experimental investigation on effect of combustion chamber geometry and port fuel injection system for CNG engine. IOSR Journal of Engineering 2: 49-54.

35. Jaichander S, Annamalai K (2013) Combined impact of injection pressure and combustion chamber geometry on the performance of a biodiesel fueled diese engine. Energy 55: 330-339. 